\title{
電力用半導体パッケージの振動解析
}

$\begin{array}{llllllll}\text { 正 員 } & \text { 守田 } & \text { 俊章 } & \text { ((株) 日立製作所) } & \text { 正 貝 } & \text { 山田 } & \text { 二 } & \text { ((株) 日立製作所) } \\ \text { 正 } & \text { 木村 } & \text { 新 } & \text { ((株) 日立製作所 }) & \text { 非会員 } & \text { 北野 } & \text { 誠 } & \text { ((株) 日立製作所) } \\ \text { 非会員 } & \text { 山本 } & \text { 弘毅 } & \text { ((株) 日立製作所) } & \text { 非会員 } & \text { 田中 } & \text { 基八郎 } & \text { (埼玉大学) }\end{array}$

\section{Vibration Analysis of Encapsulation for High Power Semiconductor Devices}

Toshiaki Morita, Member (Hitachi, Ltd), Kazuji Yamada, Member (Hitachi, Ltd), Shin Kimura, Member (Hitachi, Ltd), Makoto Kitano, Non-member (Hitachi, Ltd), Kouki Yamamoto, Non-member (Hitachi, Ltd), Kihachiro Tanaka, Nonmember (Saitama University),

\begin{abstract}
In regard to a noise from encapsulation for power semiconductor devices, we investigated the vibration action of a flange which is the main cause of noise occurrence. Furthermore, we studied the influence of the vibration on the reliability of the power semiconductor encapsulation, and looked at a plan to reduce the vibration. We found that Lorentz power caused the flange to vibrate from the magnetic flux change which accompanies switching of a main current. The flange vibrated with a maximum amplitude of $8 \mu$ with $2.5 \mathrm{kHz}$ (current: $600 \mathrm{~A}$ ). The vibration amplitude of the encapsulated semiconductor device was estimated as about $60 \mu \mathrm{m}$. At this time, the largest stress occurrence was $12 \mathrm{~kg} / \mathrm{mm}^{2}$. The value was $1 / 2$ or less that the limit fatigue of the flange composed of 42 alloy. We concluded there would be no problem regarding fatigue destruction of the flange.

Furthermore, when a vibration absorber was fixed between the flange and the insulator, the vibration of the flange could be reduced to about $1 / 10$. This measure was considered to contribute to low noise operation.
\end{abstract}

キーワード : 電力用半導体、フランジ、振動、振動吸収材、低騒音化

\section{1.はじめに}

電力用半導体が適用されるミル制御装置、車両搭載用補 助電源、駆動装置、無停電電源装置、及び電動機駆動装置 等は、省電力上高機能化が要求される傾向にあり(1)-(4)、これ に対応するには素子の高耐圧、大容量化、及びパッケージ の高信頼化が極めて重要である。素子の高耐圧、大容量化 を実現させるには、素子とパッケージの大口径化を図る必 要がある。

しかし、電力用半導体素子を適用した変換器を稼働させ ると騒音(異常音)が観測されることがあった。この騒音発 振源はトランスやコンデンサ等の周辺回路、及びパッケー ジであり、より大容量化した素子を变換器に適用した場 合、パッタージの信頼性確保に対する愁案事項となってい た。従って振動によってパッケージの信頼性が低下するか 否かを突き止める必要がある。

そこで、本研究は (1) 発振源の振動挙動を実験で定量化す る、（2）通電時の振動低減化について検討し、（3）低騒音化 のための構造を提案することを目的とした。

\section{2. 半導体装置の構造}

図1に電力用半導体パッタージの構造の1例を示す。外部 電極(アノードとカソード)材に、放熱、電気伝導、加工性 に優れた銅を配置してある。また、シリコンと銅の熱膨張

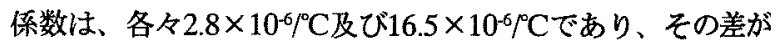
大きいため、熱膨張係数がシリコンに近いモリブデン $(5.2 \times$ $\left.10^{-6} /{ }^{\circ} \mathrm{C}\right)$ を銅ノシリコン間に設置した。ガイシはアルミナ製

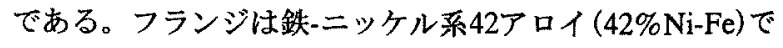
構成されている。

\section{3. フランジの振動モード}

$\langle 3 \cdot 1\rangle$ 騒音発生の支配的要因電力用半導体 パッケージのフランジには強度、耐疲労性、及びガイシ(ア ルミナ製)との接続信頼性等を考虑して42アロイが用いられ ることが多い。また、稼働時、通電する電流のスイッチン グ周波数は数100ヘルツで使用される。このとき、素子電流 スイッチング時の電流パルスによって磁性材Fe-Ni合金で構 成されたフランジは磁界から力、すなわちローレンツカを 受けると考えられる。この力の向きによってはフランジが 


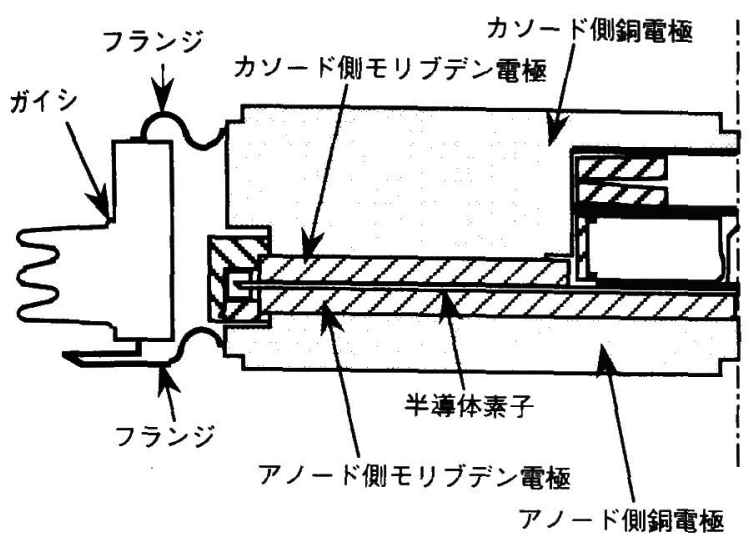

図1 電力用半導体パッケージの構造

Fig.1. Encapsulation structure for a high power semiconductor device.

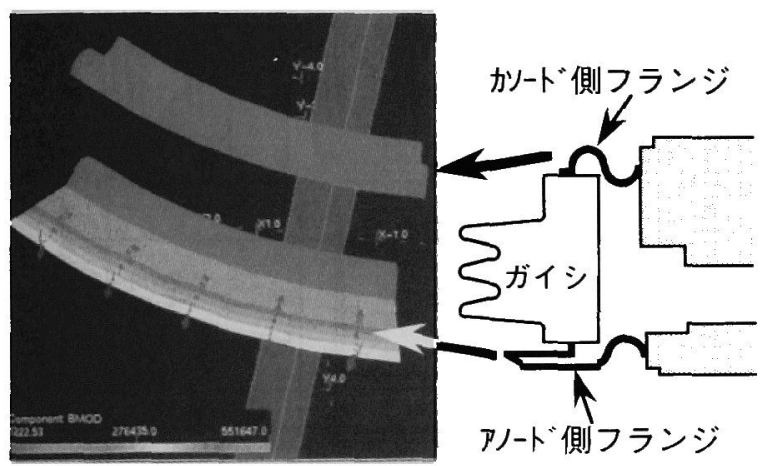

図2 フランジ部の法線方向に作用するローレンツカ解析結 果

Fig. 2. Analysis results of Lorentz power that acts in a vertical direction on a flange.

振動する可能性がある。

図2は、半導体素子を流れるパルス電流により、アノード 側フランジ平坦部に衝撃性ローレンツカ(電磁力)がフラン ジ表面に対して法線方向に作用することを電磁力解析によ り求めた結果である。解析にはOPERA-3Dを用いた。ア ノード側フランジの外周部ほど強く生じていることが判 る。このローレンツカによってフランジは振動すると考え られる。

$\langle 3 \cdot 2\rangle$ 振動モード解析図3 は有限要素法 (Finite Element Method : FEM)による振動固有值の解析結 果である。解析にはADINAを用いた。解析では5次までの 固有振動数が求められた。その振動モードも併せて図3に示 す。1次モードはガイシとフランジが一緒にアノード側に上 下に振動するモード(固有振動数 $716 \mathrm{~Hz}) 、 2$ 次はガイシとフ ランジがカソード側に上下振動するモード $(1047 \mathrm{~Hz}) 、 3$ 次 はアノード側フランジだけが片持ちはり状に下側(ガイシと 反対側）に振動するモード $(2571 \mathrm{~Hz})$ 、4次はアノード側フラ
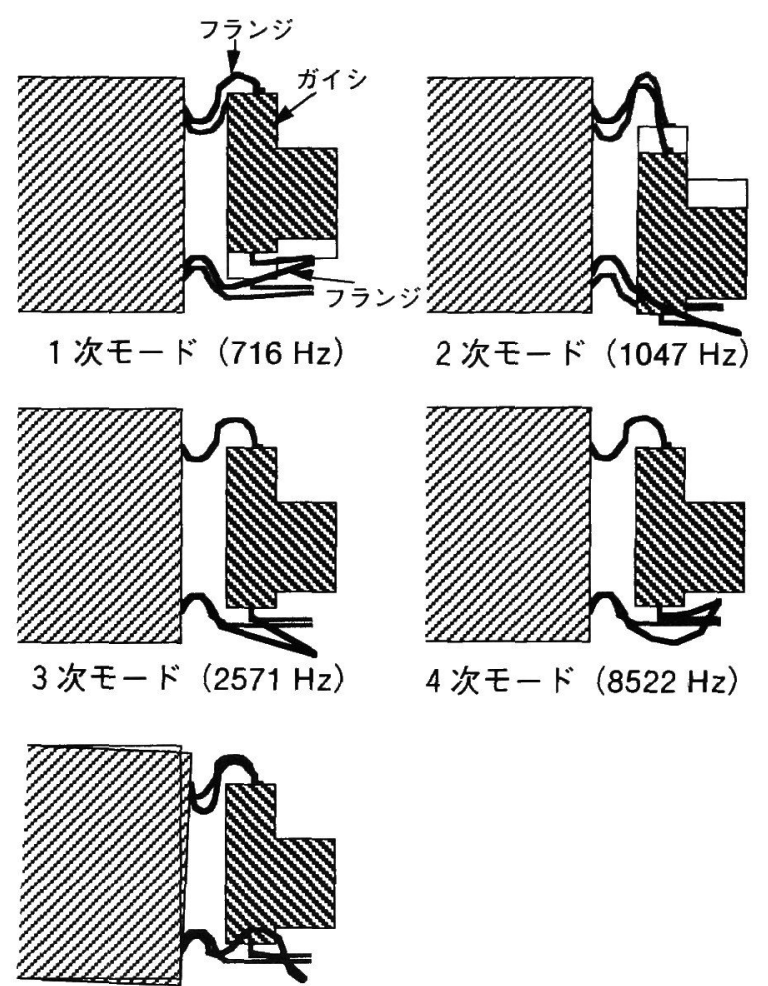

5 次モード (9376 Hz)

図3 FEM解析による振動モード

Fig. 3. Vibration mode by FEM analysis.

ンジがガイシ側に振動するモード $(8522 \mathrm{~Hz}) 、 5$ 次はガイシ が上下に、フランジはガイシ側に振動するモード $(9376 \mathrm{~Hz})$ である。

実際に振動しているモードを特定するため、単体素子の ハンマリングによって固有振動数を求めた。表1に実測結果 を示す。ガイシ軸方向(縦方向)からは750Hzと $3000 \mathrm{~Hz}$ が実 測でき、前者は1次の振動モードに対応している。またア ノード側フランジからは $2.5 \mathrm{kHz}$ 実測でき、3次振動モード に対応している。前述した電磁力解析結果、及びアノード 側フランジハンマリングで $2.5 \mathrm{kHz}$ (3次モード)が観測できる ことを考慮すると、アノード側フランジは3次の固有振動 モード、2.5kHzで振動していると考えられる。

そこで3次の振動モードに対応した応力解析を行った。こ のモードはアノード側フランジのみが上下に振動するの で、素子本体とガイシを固定し、フランジ先端部に $1 \mu \mathrm{m} の$ 強制変位を上下方向に与えた。図4にアノード側フランジ部 の最大主応力の分布を示す。この結果、アノード側フラン ジのL字コーナ部が最大応力発生部であることが判った。 フランジ先端部が $1 \mu \mathrm{m}$ 変位したとき、ここに発生する応力 值は $0.20 \mathrm{~kg} / \mathrm{mm}^{2}$ である。 
表1 ハンマリングによる固有振動数実測結果 Table 1. Measurement results of proper frequency by hammering.

\begin{tabular}{|c|c|}
\hline ハンマリング部 & 固有振動数 $(\mathrm{Hz})$ \\
\hline ガイシ軸方向 & 750（1次に対応）、3,000 \\
\hline ガイシ径方向 & $>5,000$ \\
\hline アノードフラシジ & 2,500 (3.2L \\
\hline
\end{tabular}

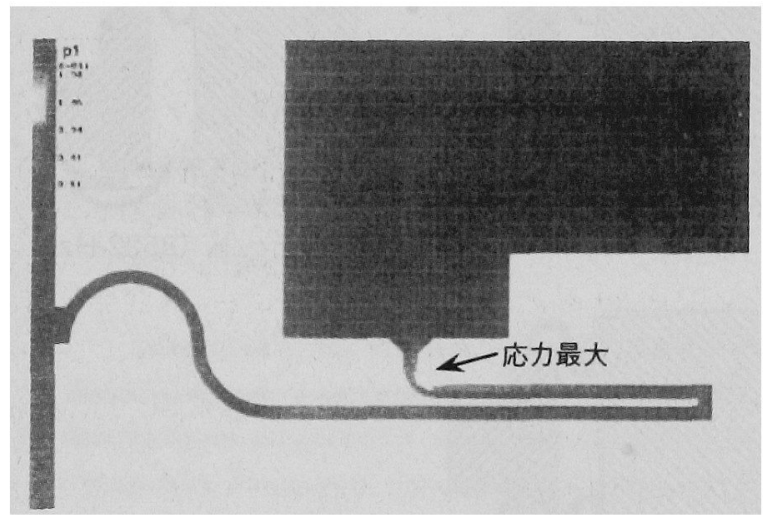

図4 アノード側フランジ部の最大主応力の分布 Fig. 4. Distribution of the maximum main stress on the anode side flange.

\section{4. フランジの振動振幅実測}

$<4 \cdot 1>$ フランジ部振動測定方法 フランジ部の 振動測定用スタックに本半導体素子をセットし、アノード 側フランジ最外周部の振動を測定した。測定にはレーザ ドップラー振動計(5) (Polytech製)を用いた。この振動計は レーザ光を測定箇所に照射し、反射波のドップラー効果か ら照射箇所の振動の速度成分を測定する装置であり、その 值から振動振幅を換算する。測定箇所を図5に示す。フラン ジ振動に影響を及ぼす因子を特定するため、(1)電流パルス 幅と周期を一定としたときのピーク電流に対するフランジ 振動振幅、(2)電流ピーク值と周期を一定としたときの電流 パルス幅に対するフランジ振動振幅、(3)電流ピーク値と電 流パルス幅を一定としたときの電流パルス周期に対するフ ランジ振動振幅、及び(4) 電流パルス幅を一定として、単一 パルス電流通電時のピーク電流值に対するフランジ振動振 幅をそれそれれ測定した。この他、（5)フランジハンマリング による振動の主周波数成分を特定した。

$<4 \cdot 2>$ アノード側フランジ部振動測定結果 図6に電流パルス幅と周期を一定としたときの電流ピーク值 $700 \mathrm{~A}$ 時の測定波形解析例を示す。振動波形に対する Fast Fourier Transform(FFT) カーブから通電時のフランジ主振 動数は2.5kHzであることが判った。また、本測定から電流 ピーク値に関係なく常に主振動数成分は $2.5 \mathrm{kHz} ゙$ あること

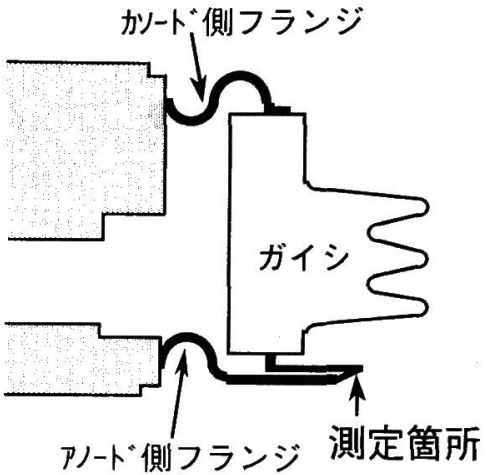

図5 振動振幅測定筒所

Fig. 5. Place for vibration amplitude measurements.

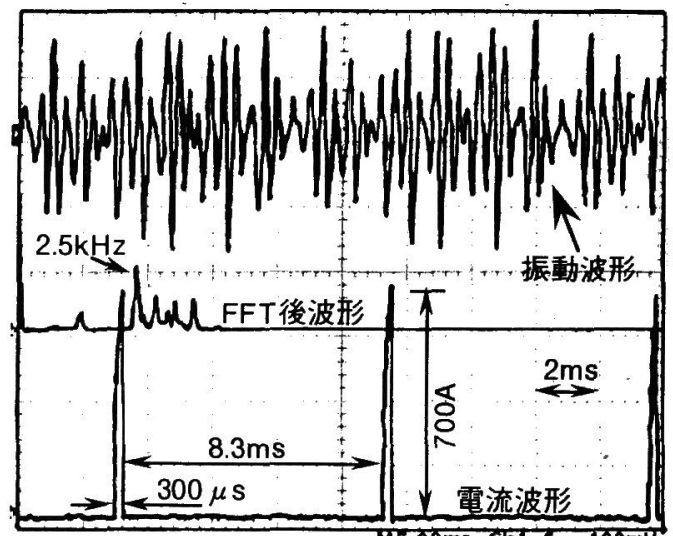

図6 電流ピーク值700A時の測定波形解析例(電流パルス幅 と周期を一定）

Fig. 6. Example analysis of measurement waveform for a current peak value 700A (current pulse width and cycle: constant).

も確認した。

なお、振動数成分は、(2)電流ピーク值と周期を一定とし たときの電流パルス幅に対するフランジ振動振幅、(3)電流 ピーク值と電流パルス幅を一定としたときの電流パルス周 波数に対するフランジ振動振幅、及び(4)電流パルス幅を一 定として、単一パルス電流通電時のピーク電流值に対する フランジ振動振幅測定時にもそれぞれ同様に分析し、全て の場合において電流パルス波形に関係なくフランジ振動の 主振動数成分は $2.5 \mathrm{kHz}$ であることを確認した。以後に示す 振幅測定結果は振動数 $2.5 \mathrm{kHz}$ に対する振幅である。

周期を $8.3 \mathrm{~ms}$ 一定とした場合において、図7に電流パルス 幅を $300 \mu \mathrm{s}$ としときのピーク電流值に対するフランジ振 動振幅測定結果を、図8に電流ピーク值を500Aとしたとき の電流パルス幅に対するフランジ振動振幅測定結果を、そ れぞれ示した。これらの結果からフランジ振動振幅はピー ク電流値に対してほぼ直線的に増加し、かつ電流パルス幅 


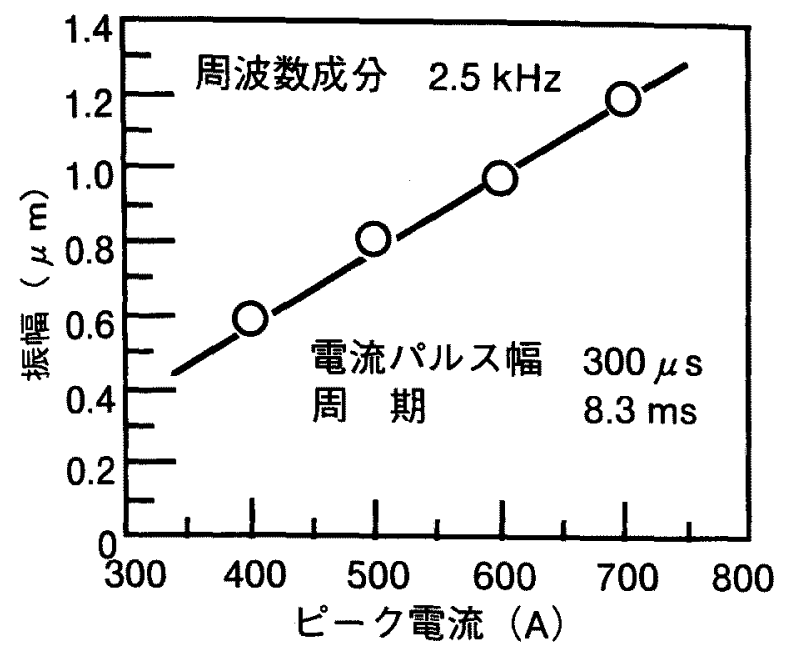

図7ピーク電流值変化時のフランジ振動振幅測定結果 (電

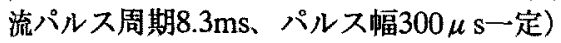

Fig. 7. Measurement results of vibration amplitude of flange for changes in peak current value (current pulse cycle: $8.3 \mathrm{~ms}$; pulse width: $300 \mu \mathrm{s}$ )

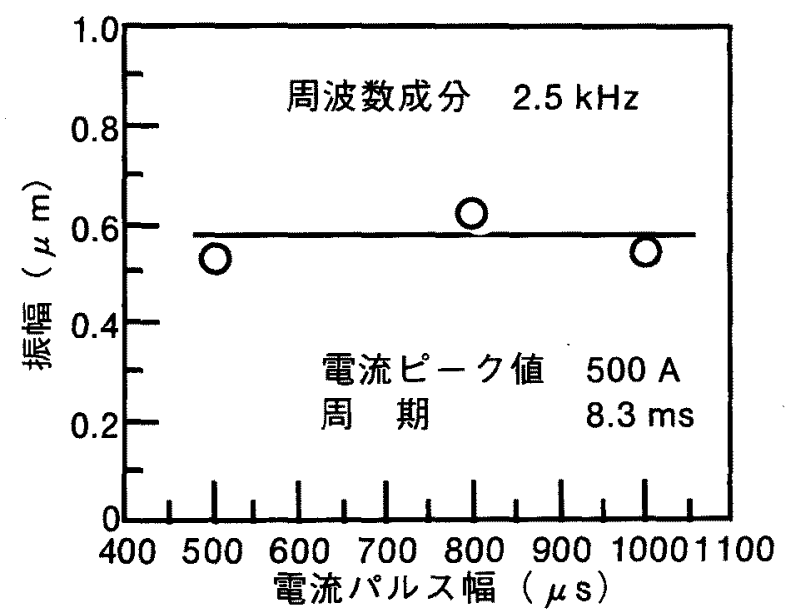

図8 電流パルス幅変化時のフランジ振動振幅測定結果(電 流パルス周期8.3ms、ピーク值 $500 \mathrm{~A}$ 一定)

Fig. 8. Measurement results of vibration amplitude of flange for changes in current pulse width (current pulse cycle: $8.3 \mathrm{~ms}$; peak value: $500 \mathrm{~A}$ ).

に依存しないことが判った。

図9は電流ピーク值を400A、電流パルス幅を $300 \mu \mathrm{s}$ 一定と して、電流パルス周波数に対するフランジ振動振幅の測定 結果である。特定の周波数に対して振幅が大きくなる現象 が生じていることが判る。この特異点は電流パルス周波数 がフランジの主振動数 $2.5 \mathrm{kHz}$ の $1 / \mathrm{n}$ ( $\mathrm{n}$ =整数) 倍と一致した 時に生じており (共振状態)、 $\mathrm{n}=4$ 、すなわち電流パルス周 波数 $600 \mathrm{~Hz}$ 時にはフランジは約 $8 \mu \mathrm{m}$ の振幅で振動してい る。

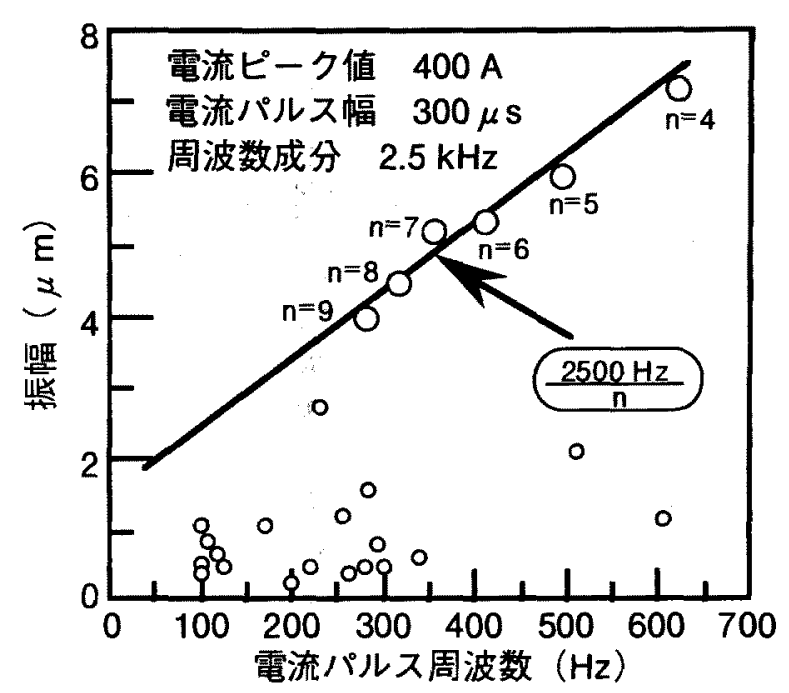

図9電流パルス周波数変化時の振幅(電流ピーク值400A、 パルス幅 $300 \mu \mathrm{s}$ 一定)

Fig. 9. Amplitude for changes in current pulse frequency (current peak value: $400 \mathrm{~A}$; pulse width: $300 \mu \mathrm{s}$ ).

図10(a)に、パルス幅300 $\mu \mathrm{s}$ の単一パルス電流を通電し、 電流ピーク值700A時の測定波形解析例を、(b)にピーク電 流值に対するフランジ振動振幅測定結果をそれぞれ示す。 図7と同様にフランジの振動振幅は電流パルスピーク值に比 例して增大した。

$$
\text { 〈4・3〉 フランジの振動挙動のまとめ }
$$

(1)加振力：主電流スイッチング時の大きなdi / d t に対応し た磁束変化によるローレンツカがアノードフランジ部に衝 撃的に加えられる。

(2)振動 : 衝撃的に加えられるローレンツカによってアノー ドフランジが3次モードの固有振動数 $(2.5 \mathrm{kHz})$ で振動する。

(3)電流パルス周期との共振：アノードフランジが固有振 動数で振動している時、振幅を增加させる形で電流スイッ チングによる䘖撃力が加えられると、フランジの振幅は增 幅される(以下共振加振状態と記す)。

実機において、罒9亿示した共振加振状態で傢働される場 合、フランジの疲労破壊が賏念される。共振加振状態時に フランジに生じる応力值を把握し、さらに、振動を低減さ せるための检討を行ら必要がある。

\section{5. 振動によるフランジの疲労寿命推定}

図11 K Fe-Ni合金の静的強度を示す。42アロイ $(42 \% \mathrm{Ni}-$ $\mathrm{Fe})$ の.2\%耐力は拉よそ $50 \mathrm{~kg} / \mathrm{mm}^{2}$ であることが判る。多く の材料の場合、疲労限は $0.2 \%$ 耐力の $1 / 2$ 以上ある(6) 加ら、 42 アロイの疲労限は $25 \mathrm{~kg} / \mathrm{mm}^{2}$ 程度と推定される。

ところで、実機は電流パルス周波数600 $\mathrm{Hz}$ 付近、定常電流 パルス振幅3000A程度で使用される。フランジ振動は電流 に比例して增大するので、図9より電流パルス周波数 $600 \mathrm{~Hz}$ 


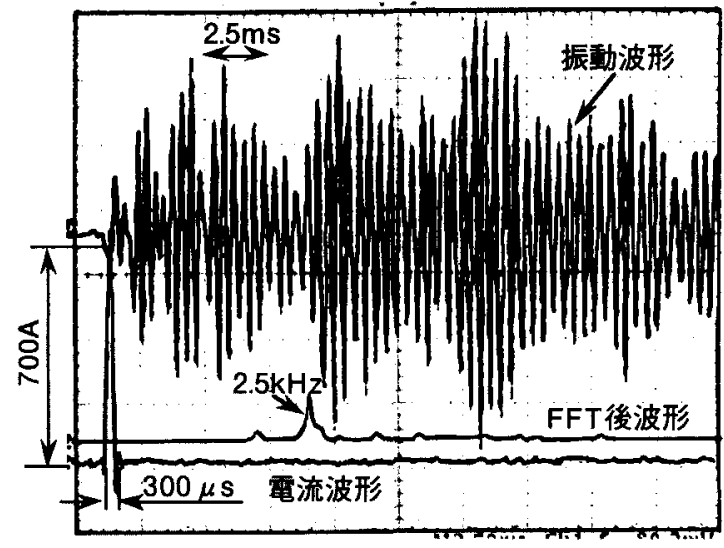

（a）電流ピーク值700A時の測定波形解析

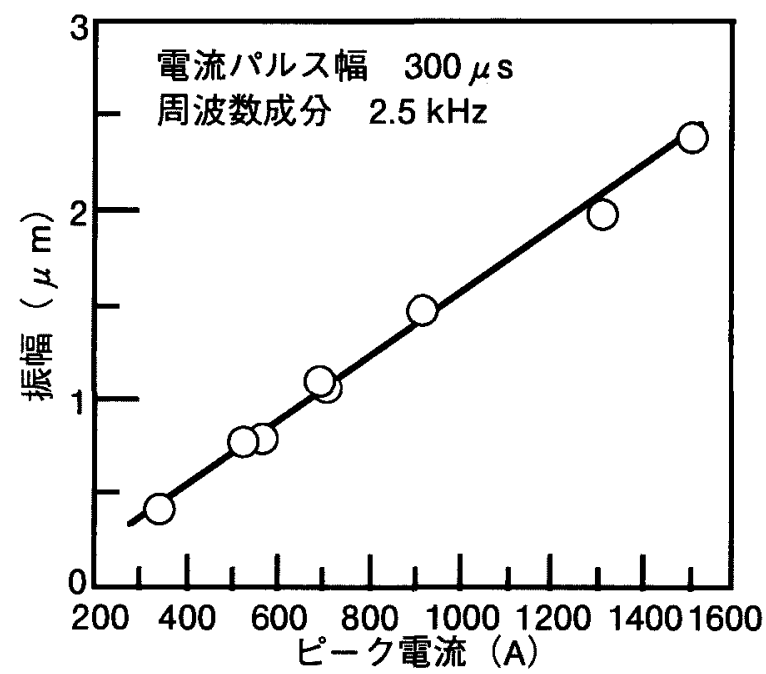

(b) 電流ピーク值に対する振幅

図10 単一パルス電流通電時の振幅(電流パルス幅 $300 \mu \mathrm{s}$ 一定)

Fig. 10. Amplitude when electricity is turned on at a simple pulse current (current pulse width: $300 \mu \mathrm{s}$ ).

$(\mathrm{n}=4)$ 、電流ピーク值 $400 \mathrm{~A}$ 時の振幅は $8 \mu \mathrm{m}$ であるから実機 では、

$$
3000 / 400 \times 8 \mu \mathrm{m}=60 \mu \mathrm{m}
$$

程度の振動振幅が予想される。従って $\mathrm{n}=4$ の周波数の電流 パルス時の3次モード振動による最大発生応力は、

$$
60 \times 0.20 \mathrm{~kg} / \mathrm{mm}^{2}=12 \mathrm{~kg} / \mathrm{mm}^{2}
$$

程度と推定できる。共振周波数の1/4倍のパルス周波数で運 転されても発生応力は疲労限の $1 / 2$ 以下であり、共振状態を はずれれば応力は1/10以下になる(図9参照)ことから、フラ ンジの疲労破壊については問題無いと考えられる。

しかし、試作変換器の6000ボルト稼働時の騒音が大きい ので振動振幅を低減させて騒音を抑える必要がある。

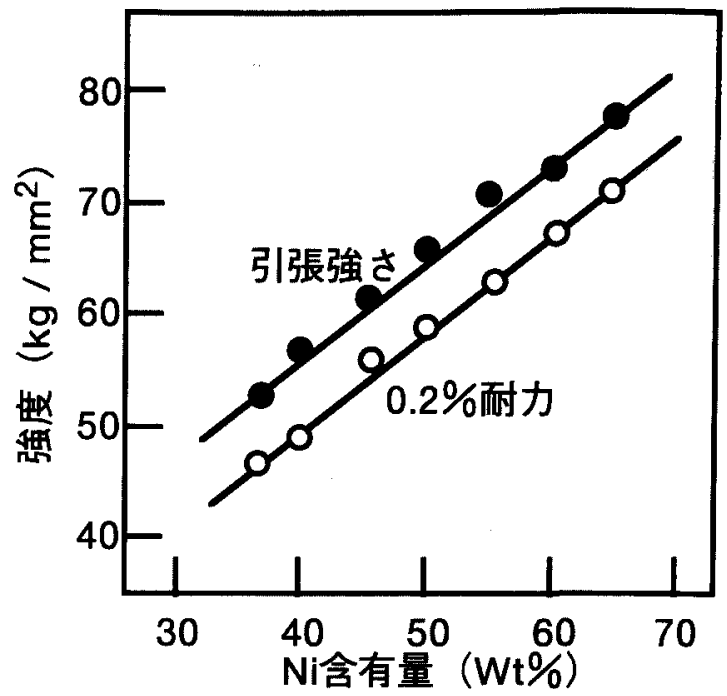

図11 Fe-Ni合金の静的強度

Fig. 11. Static strength of the Fe-Ni alloy.

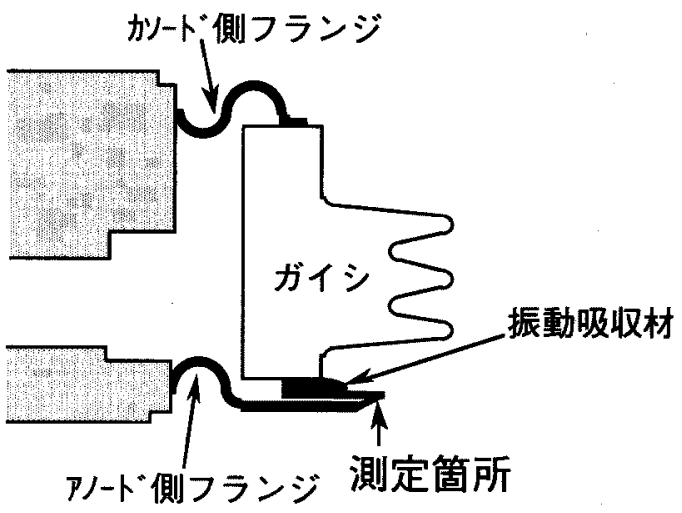

図12 振動吸収材装着位置と振動測定箇所 Fig. 12. Installation position of vibration absorber and places of vibration measurements.

\section{6. 振動低減の検討}

振動振幅を低減させるための最む有力な手段は、発生す る応力を低減させることである。振動によって応力が最も 大きく発生する筒所は、図4に示したようにフランジの振動 する部分と振動しない部分との境界部である。そこでこの 領域全体に発生した底力を分散、吸収させるため、振動吸 収効果のある材料を装着し、このパッケージに対して前述 同様の振動振幅を湘定した。図12に振動吸収材の装着位置 と振動測定位置を示す。

図13 (a) は電流ピーク値を400A、電流パルス幅 $300 \mu \mathrm{s}$ 一定 


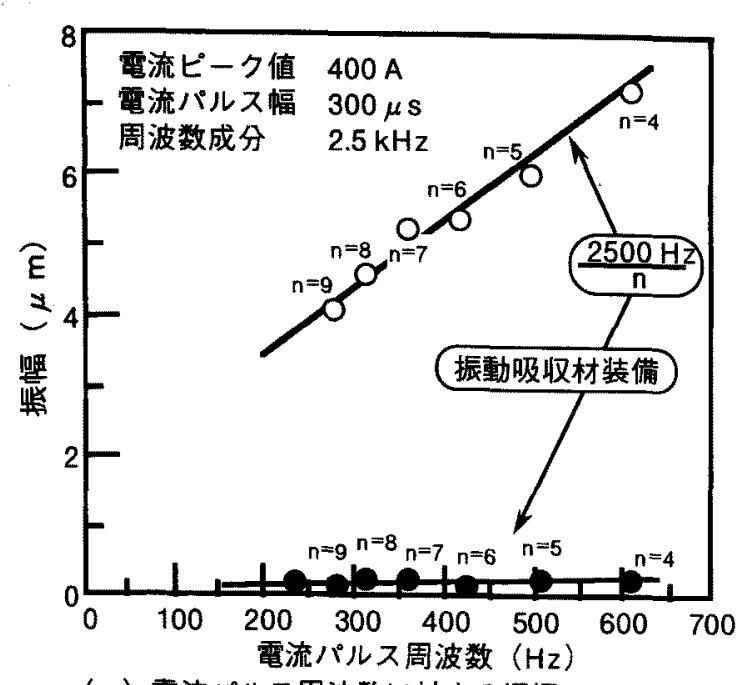

（a）疍流パルス周波数に対する振幅

（電流ピーク值400A、パルス幅 $300 \mu \mathrm{s}$ 一定）

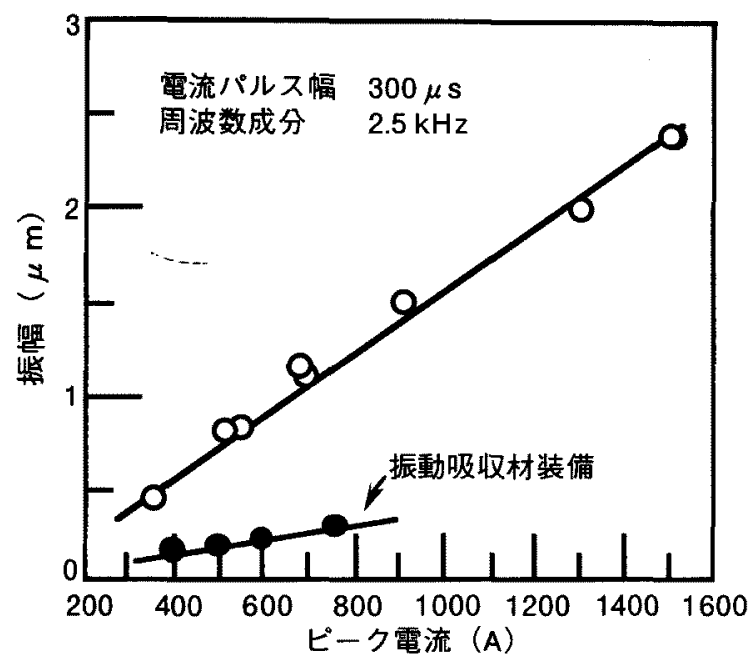

(b) 単一パルス通電時のピーク電流值に対 する振幅（電流パルス幅 $300 \mu \mathrm{s}$ 一定）

图13振動吸収材装着時のフランジ振動振幅測定結果

Fig. 13. Measurement results of vibration amplitude of flange with an installed vibration absorber.

として、振動吸収材を装借したパッケージのフランジ最外 周部の振動振幅を電流パルス周波数に対して測定したもの である。比較のため振動吸収材を装備しないパッケージの 振幅む示した(図9参照)。振動吸収材を装着すると通電する 電流パルス周波数がフランジの固有振動数の $1 / \mathrm{n}$ 倍に一致し ても振幅は非常に小さく、装着しない場合の1/10以下に低減 している。さらに振動に伴って発生する騒音も非常に小さ くなった。

図13(b)は振動吸収材を装着したパッケージに対して測定 した、パルス幅を $300 \mu \mathrm{s} 一$ 一定とした単一電流パルス通電時
のピーク電流值に対するフランジの振動振幅の関係を示し たものである。吸収材を装着しないパッケージの振幅も示 してある。図10(b) と同様に、フランジの振動振幅は電流 ピーク值に対してほぼ直線的に増加した。しかし勾配は1/5 程度に隇少してい抢り、振動振幅減少のために応力発生部 に振動吸収材を装着する効果は大きいことが判る。

\section{7. 結言}

稼価時における大口径電力用半導体パッタージの振動解 析を行い、振動挙動を明確化した。さらに信賴性に与える 振動の影響と振動振幅低隇策について検討し、以下の結論 を得た。

(1) 発振源はアノードフランジの固有振動数 $2.5 \mathrm{kHz}$ による 振動である。主電流のスイッチングで生じる衝撃性のロー レンツカで加振され、振動する。

(2) 通電する電流パルス周波数がフランジの固有振動数の 1/整数倍に一致したとき、フランジ振幅は大きくなる(共振 加振状態，。

(3) フランジの振動振幅は電流ピーク值に比例して增大 し、電流パルス幅には依存しない。

(4) 実稼做時のフランジ最大振動振幅は約 $60 \mu \mathrm{m}$ と推定で きる。このときの最大発生応力は $12 \mathrm{~kg} / \mathrm{mm}^{2}$ で、フランジを 構成する $42 ア$ ロイの疲労限 $25 \mathrm{~kg} / \mathrm{mm}^{2}$ の1/2以下であり、フ ランジの疲労破壊は無いと推定できる。

(5) フランジとガイシの間に振動吸収材を装着すると、フ ランジ振動振幅を1/10程度に低隇できる。

\section{謝辞}

本研究の遂行にあたり、測定データの吟味に際し、大変 有益な助言を頂いた日立製作所電力電機グループ大みか電 機本部飛世正博氏に深く感謝申し上げる。また、振動測定 に際し、御助言、御助力頂いた根原良一氏、小泉正博氏、 高橋和弥氏、矢川正行氏 (以上日立研究所)、電磁力解析に 御助力頂いた日立研究所伊藤元哉氏、さらに研究結果につ いて御意見、御討論頂いた赤羽根克己氏、桜田修六氏(以上 電力電機グループ日立電機本部)、門馬直弘氏、小林裕氏 (以上曰立研究所) に深く感謝申し上げる。

(平成11年10月26日受付)

\section{文献}

（1）桜田修六：「GTOサイリス夕」, 電気評論, No.9, 847(1987)

（2）中川勉：「パワーデバイスはここまで進んだ」，電気学会誌，114, 161(1994)

（3）松田秀雄：「高酎圧・大容量サイリスタとダイオード」，OHM， No.6, 47(1994)

(4) G. Humpston: "Recent Development in Silicon / Heat - Sink Assemblies for High Power Device Applications", GEC Review, 7, 67 (1991)

（5）㮛原良一、高槅幸、加藤光雄、坪崎邦宏、渡辺宏：「振動周波数 70、130、172kHzの超音波ボールボンディング」，溶接学会論文 集, 15, 161(1997)

(6) 北野私信 


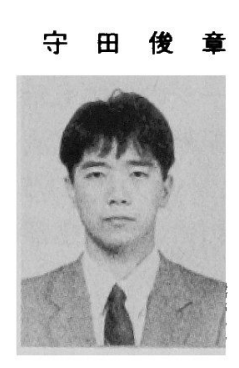

（正員）1993年九州大学大学院材料開発専攻修士 課程修了。同年日立製作所入社、日立研究所勤 務。IGBT、サイリスタ等のパワー半導体パッ ケージング、及びLSI実装技術の開発に䛤事。日 本金属学会、応用物理学会、溶接学会各会員。

山 田 - = (正貝) 1971年名古屋工業大学大学院電気工学専

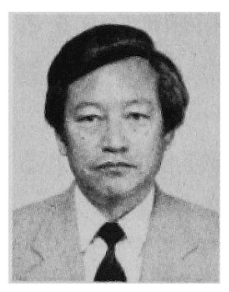
攻修士課程修了。同年日立製作所入社、日立研究 所勤務。半導体センサ、半導体実装の研究に従 事。工学博士。現在、日立研究所主幹研究員。電 子情報通信学会, エレクトロニクス実装学会、 IEEE各会員。

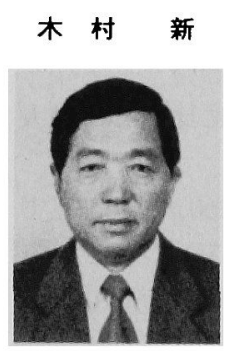

（正員） 1965 年旭川工業高校電気科卒業。同年日 立製作所入社、日立研究所勤務。以来パワーデバ イスの開発、応用研究に従事。

(非会員) 1980年早稲田大学大学院機械工学専攻 修士課程修了。同年日立製作所入社、機械研究所 勤務。パワーデバイス、LISパッケージ及びこれら の実装構造の信頼性に関する研究開発に従事。工 学博士。現在は研究企画業務に従事。日本機械学 会会員。

山 本弘 媇 (非会員) 1990年筑波大学大学院理工学研究科修

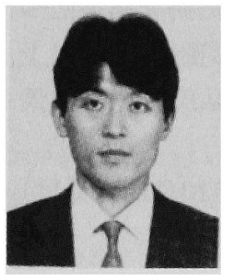
士課程修了。同年日立製作所入社、日立研究所勤 務。電磁場解析、及び回転機の研究開発に従事。 日本物理学会会員。

田 中 基八郎 (非会貝) 1975年早稲田大学大学院機械工学専攻 修士課程修了。同年日立製作所入社、機械研究所 配属。原子カプラント、ICパッケージの構造、振 動、感度解析を担当後、メカトロニクス製品、家 電品等の振動、馶音解析に従事。工学博士。現在 埼玉大学教授。日本機械学会会員。 